УДК 551.234. 556.314

\title{
МИКРОКОМПОНЕНТНЫЙ СОСТАВ НИЗКОМИНЕРАЛИЗОВАННЫХ АЗОТНЫХ ТЕРМ ГИССАРСКОГО ХРЕБТА (ПАМИРО-АЛАЙСКАЯ ГОРНАЯ СИСТЕМА)
}

\author{
Демонова Анна Юрьевна',
} danna1985@yandex.ru

\author{
Харитонова Наталья Александровна ${ }^{1,2}$, \\ tchenat@mail.ru \\ Брагин Иван Валерьевич², \\ bragin_ivan@mail.ru \\ Челноков Георгий Алексеевич², \\ geowater@mail.ru
}

\author{
Тарасенко Ирина Андреевна², \\ tarasenko irina@mail.ru \\ 1 Московский государственный университет им. М.В. Ломоносова, \\ Россия, 119991, г. Москва, ГСП-1, Ленинские горы, 1. \\ 2 Дальневосточный геологический институт Дальневосточного отделения Российской академии наук, \\ Россия, 690022, г. Владивосток, пр. 100 лет Владивостоку, 159.
}

\begin{abstract}
Актуальность исследования обусловлена необходимостью разумного использования природных ресурсов и термоминеральных вод, в частности уникального бальнеоклиматического курорта Ходжа-Оби-Гарм, локализованного в центральной части отрогов южного склона Гиссарского хребта. Одной из наиболее актуальных проблем для исследования остается изучение микрокомпонентного состава данных вод.

Цель. Исследование этих вод начато в середине XX в., однако микрокомпонентный состав вод до сих пор изучен плохо. Основной целью данной работы является детальное исследование распределения в термальных водах месторождения Ходжа-ОбиГарм химических элементов, а также выявление источников их поступления, механизмов и факторов мобилизации и фракционирования.
\end{abstract}

Объекты: подземные воды и водовмещающие породы месторождения низкоминерализованных термальных вод Ходжа-ОбиГарм, которое приурочено к Памиро-Алайской горной системе (Таджикистан).

Методы. Приведенные в работе результаты химических анализов водной фазы и водовмещающих пород были выполнены в аналитических подразделениях Дальневосточного геологического и Дальневосточного океанологического институтов ДВО РАН. Основные катионы и анионы термальных вод определялись методом жидкостной ионной хроматографии (HPLC-10AVp, SHIMADZU), а микро- и рассеянные элементы анализировались с использованием плазменно-оптической эмиссионной спектрометрии (ICP-AES, Plasmaquant-110) и индуктивной плазменной масс-спектроскопии (ICP-MS, Agilent 7500c). Для более полного понимания процессов, происходящих в системе вода-порода, использовались программы: AQUACHEM 5.1, WATERQ4F, PHREEQC. Maкрофотографии водовмещающих пород выполнялись с помощью цифровой фотокамеры Nikon, а петрографические исследования - с помощью стереоскопического микроскопа Leica-E, оснащенного цифровой фотокамерой. Определение содержания главных элементов в образцах было выполнено методом атомно-эмиссионной спектрометрии на спектрометре iCAP 7600 Duo (Thermo Scientific) и методом масс-спектрометрии с индуктивно связанной плазмой на спектрометре Agilent 7500 c (Agilent Techn.)

Результаты. Приведены результаты комплексных исследований подземных вод и водовмещающих пород месторождения низко минерализованных термальных вод Ходжа-Оби-Гарм, которое приурочено к Памиро-Алайской горной системе (Таджики(тан). По условиям формирования изученные термальные воды принадлежат к трещинно-жильными водам, циркулирующим в пределах массивных интрузий, локализованных в зоне альпийской складчатости. По химическому составу термальные воды месторождения Ходжа-Оби-Гарм относятся к маломинерализованным (до 450 мг/л) хлоридно-сульфатно-гидрокарбонатным натриево-кремнистым водам. Воды обогащены фтором (до 17 мг/л), литием (до 1,03 мг/л), рубидием (до 123 мкг/л), цезием (около 205-230 мкг/л), мышьяком (до 5,7 мкг/л) и радоном (до 815 Бк/л). Также проведенные исследования показывают, что редкие элементы в скальных породах месторождения образуют в соответствии с их содержанием следующую последовательность: $R b>T h>S c>G a>U>>C d$. Термальные воды месторождения в значительной мере обогащены Rb, который имеет наибольший среди редких элементов коэффициент водной миграции. Далее следуют Ga, остальные элементы присутствуют в «следовых» количествах. При движении из глубин к поверхности термальные воды интенсивно взаимодействуют с водовмещающими породами, растворяют и выщелачивают их. Во время данного процесса происходит интенсивное выщелачивание многих микрокомпонентов ( $L a, R b, Z r$, Ba, Li и др.) и концентрирование их в водах.

\section{Ключевые слова:}

Термальные воды, гидрогеологические условия, водовмещающие породы, микрокомпоненты, Таджикистан.

\section{Введение}

Азотные термы привлекают внимание многих ученых всего мира в течении нескольких десятиле- тий, но вопросы, касающиеся их генезиса и формирования состава подземных вод, остаются до сих пор дискуссионными [1-6]. Гидрогеологиче- 
ские условия их проявления уже детально рассмотрены в научной литературе [2, 4, 5-15]. Но не до конца оценены масштабы взаимодействия термальных вод с водовмещающими породами, и не определен характер термодинамического равновесия [12, 16-18].

В большинстве случаев термоминеральные воды характеризуются бальнеотерапевтическими свойствами и высоким теплоэнергетическим потенциалом. Экономическая целесообразность использования термоминеральных вод подтверждена многолетней практикой оздоровления людей при бальнеолечении, применения лечебно-столовых бутилированных минеральных вод, использования энергии вод в целях теплофикации (обогрева), получения из минеральных растворов редких металлов и химических элементов [2, 19].

В настоящее время на территории Таджикистана выявлено свыше 125 проявлений минеральных вод различного химического состава и температуры. На базе некоторых источников работают крупные курорты и здравницы, которые составляют санаторно-курортный комплекс страны. Одним из наиболее крупных и широкоизвестных курортов является бальнеологический курорт Ходжа-ОбиГарм (рис. 1), основным лечебным компонентом которого являются азотные низкоминерализованные термальные воды. Курорт расположен в 48 км к северу от г. Душанбе в южных отрогах Гиссарского хребта Памиро-Алайской горной системы на высотах 1740-1960 м над уровнем моря [2, 3, 6, 19-25].

Гиссарский хребет - это мощный снежный хребет, почти на всём протяжении лежащий в пределах Таджикистана. Он служит водоразделом между бассейнами рек Зеравшана и Аму-Дарьи. В верховьях Зеравшана Гиссарский хребет сливается с Туркестанским хребтом. На всем протяжении от пер.
Матча и до массива Хазрет-Султан Гиссарский хребет поднимается выше снеговой линии и несет на себе многочисленные, нередко большие ледники, которые являются основными источниками питания крупных рек и подземных вод [19, 21, 22, 26].

В административном отношении район курорта Ходжа-Оби-Гарм относится к Варзобскому району. Данный район представляет собой высокогорную, сильно расчлененную область, характеризующуюся резкими колебаниями высотных отметок и высокой сейсмической активностью [26]. Сам курорт относится к одноименному месторождению термальных вод Ходжа-Оби-Гарм. Это один из тех немногих курортов по всему миру, где в качестве лечебного средства применяется так называемый радиоактивный пар [2, 3, 6, 19-25].

Весьма важной является роль микрокомпонентов в процессах, происходящих в системе вода-порода. Микрокомпоненты содержатся в подземных водах, как правило, в малых количествах, определяемых миллиграммами, микрограммами и долями микрограммов в одном литре. Но иногда их концентрации достигают количеств, соизмеримых с макрокомпонентами. Поэтому их концентрации и формы нахождения необходимо учитывать при изучении процессов перераспределения вещества между жидкой и твердой составляющими. Несмотря на то, что их содержание в воде невелико, зачастую именно микрокомпоненты оказывают существенное влияние на здоровье человека, особенно когда дело касается лечебных минеральных вод. Микрокомпоненты представлены химическими элементами, которые имеют низкий кларк в литосфере и соединения которых отличаются низкой растворимостью. Микрокомпонентами считаются: бром, йод, фтор, бор, литий, рубидий, цезий, стронций, барий, мышьяк, молибден, медь, кобальт, цинк, свинец, ванадий, никель и др.

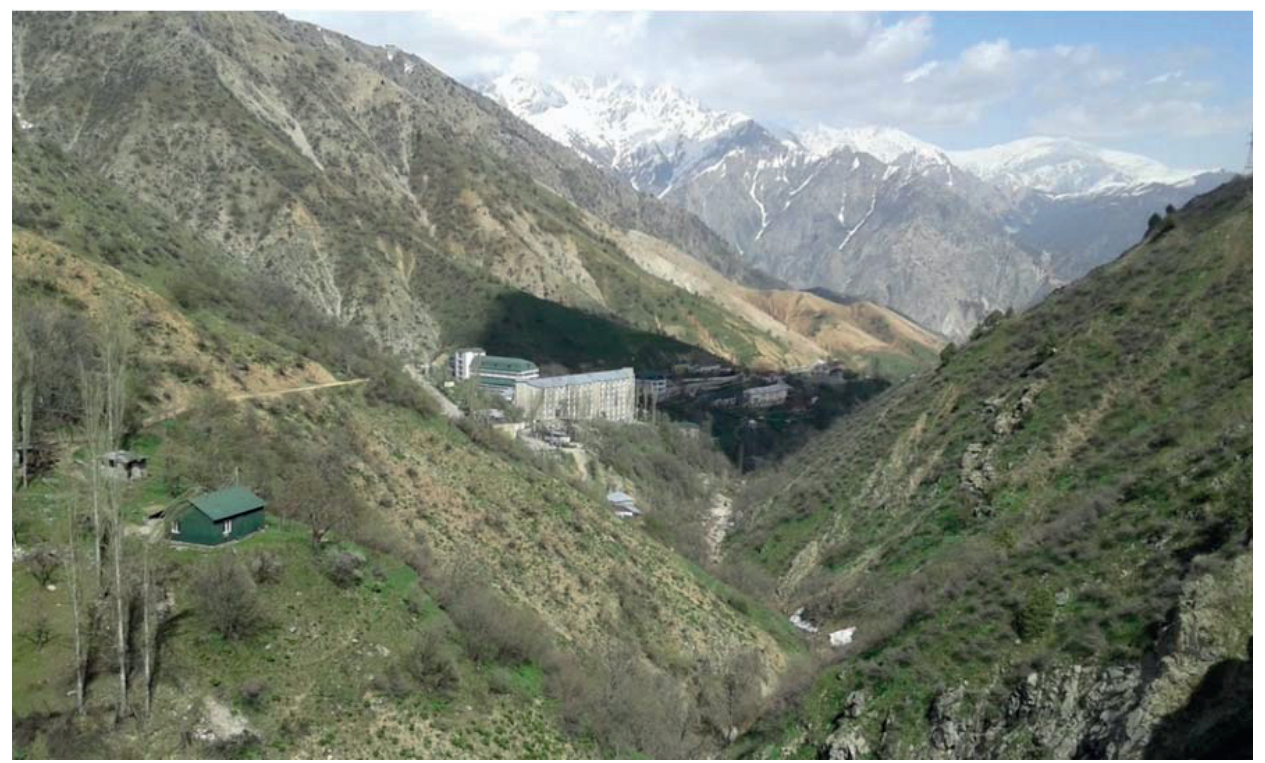

Pис. 1. Общий вид бальнеологического курорта Ходжа-Оби-Гарл

Fig. 1. General view of Khodja-Obi-Garm SPA center 
Макрокомпонентный состав термальных вод месторождения Ходжи-Оби-Гарм достаточно хорошо изучен [3], в то время как их микрокомпонентный состав исследован в не полной мере. В данной статье приводятся новые данные о микрокомпонентном составе вод месторождения и делается попытка выявить источники и механизмы поступления ряда микрокомпонентов в воду.

\section{Объект исследования}

В геологическом строении месторождения Ходжа-Оби-Гарм принимают участие кристаллические массивы, представленные магматическими породами (гранитами, гранодиоритами, гранит-порфирами) среднего и нижнего карбона. Интрузии перекрыты чехлом четвертичных отложений. Особенно широко развиты четвертичные отложения в долинах рек. В юго-западной части района палеозойские образования перекрыты нижнемеловыми осадками, песчаниками и глинами (рис. 2) [2, 3, 6, 7, 19-25].

В тектоническом отношении участок термоминеральных вод относится к окраине северной части Ходжа-Оби-Гармской зоны разрывного нарушения, по которому происходило перемещение блоков. Разрывное нарушение имеет почти широтное простирание и располагается вдоль основания левого склона реки Ходжа-Оби-Гарм [3, 20, 24, 26]. По площади месторождение совпадает с зоной новейшего горообразования, охватывающей как древние кристаллические массивы и складчатые области, так и области молодого орогенеза, связанные с развитыми крупными молодыми глыбовыми или складчатыми поднятиями и глубокими межгорными опусканиями [3, 20, 24, 26].

В гидрогеологическом отношении, в силу изменчивости литологического состава и сложности
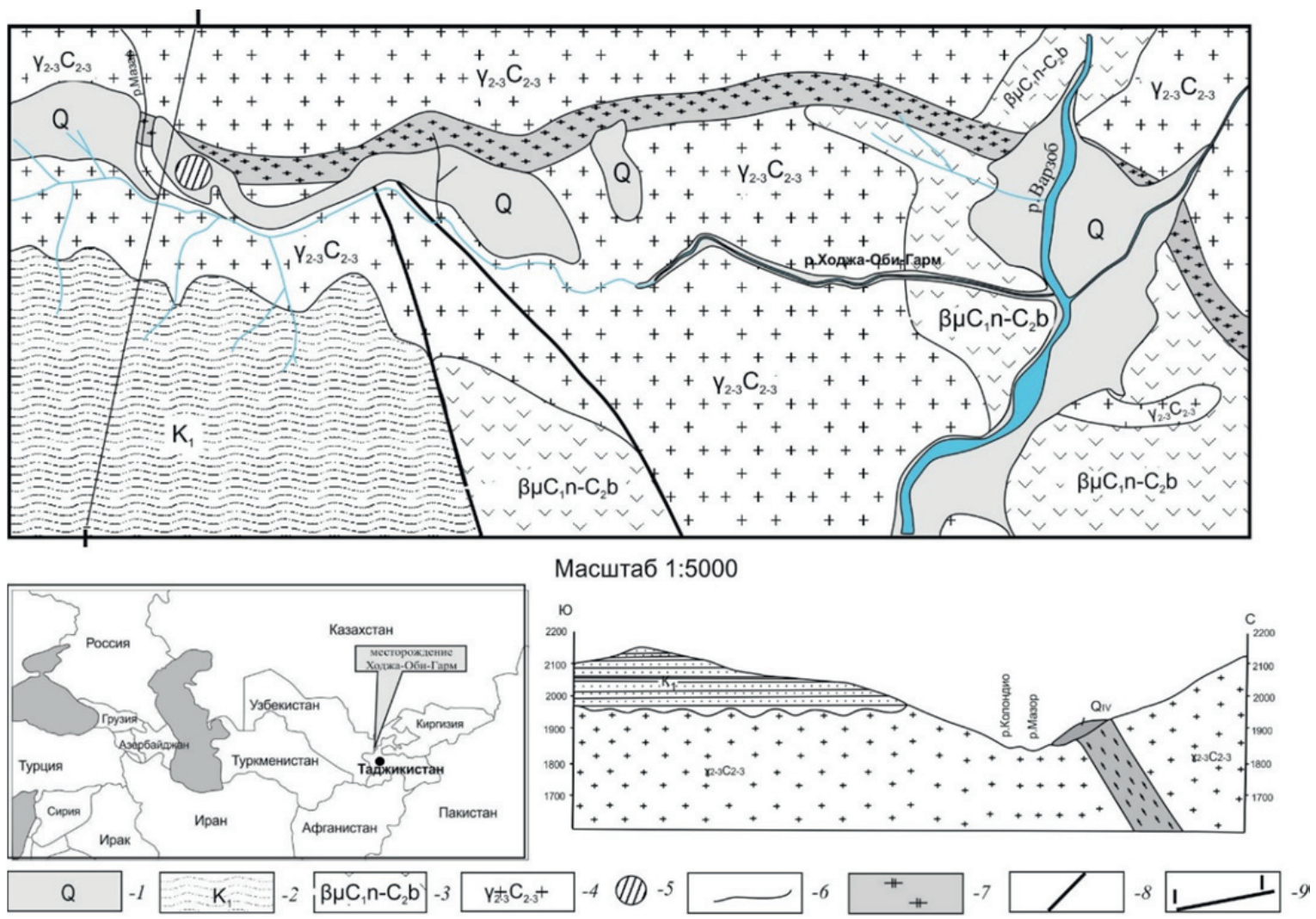

Рис. 2. Местоположение, геолого-гидрогеологическая карта и гидрогеологический разрез-схема месторождения Ходжа-Оби-Гарм. Карта и разрез построены по материалам производственных отчетов (А.А. Шапар, В.Г. Туев, 1967) с дополненияли и исправлениями авторов, где: 1 - поровые воды в аллювиальных и пролювиальных четвертичных отложениях; 2 - водоносный комплекс нижнемеловых отложений (песчаники, прослои мергеля, известняков); 3 - водоносный комплекс в эффузивной толще верхнего и среднего отделов каменноугольной системы намюрского и башкирского ярусов (базальты); 4 - водоносный колплекс в интрузивных породах средне-верхнекаменноугольного возраста (граниты, гранодиориты, диориты); 5 - участок распространения термальных вод Ходжа-Оби-Гарм; 6 - границы распространения водоносных комплексов; 7 - зона Ходжа-Оби-Гармского разлома; 8 - линии тектонических нарушений; 9 - линия геолого-гидрогеологического разреза [3]

Fig. 2. Location, geological-hydrogeological map, and hydro-geological section of the Khoja-Obi-Garm deposit. The map and the section are constructed by the materials of production reports (A.A. Shapar, V.G. Tuev, 1967) with additions and corrections of the authors: 1 are the pore waters in alluvial and proluvial quaternary sediments; 2 is the water-bearing complex of Lower Cretaceous sediments Sandstones (interlayers of marlstones and limestones); 3 is the water-bearing complex in the effusive stratum of the upper and middle series of the carboniferous system of Namur and Bashkirian stages (basalts); 4 is the water-bearing complex in intrusive rocks of the Middle-Upper Carboniferous age (granites, granodiorites, diorites); 5 is the site of distribution of mineral waters of Khoja-Obi-Garm; 6 are the boundaries of water-bearing complexes; 7 is the Khoja-Obi-Garm fault zone; 8 are the lines of tectonic disturbances; 9 is the geologic-hydrogeological section line [3] 
тектонических условий, на месторождении Ходжа-Оби-Гарм были выделены водоносные комплексы, где подземные воды приурочены к породам стратиграфического подразделения (рис. 2). Термальные воды по условиям циркуляции относятся к трещинно-жильным водам гранитов средне-нижнекаменноугольного возраста. Водообильность трещиноватых гранитов на площади месторождения распределяется неравномерно. Максимальные расходы трещинно-жильных вод получены скважинами, вскрывшими основной очаг разгрузки. Естественные очаги разгрузки в виде грифонов проявляются в эрозионных ущельях, прорезающих гранитные массивы. Питание трещинножильных вод инфильтрационное, чему благоприятствует значительная раздробленность гранитов. В процессе фильтрации по разломам воды прогреваются, изменяют свой химический состав и разгружаются в рыхлые четвертичные отложения, формируя месторождение [3, $6,19,24,25]$.

В пределах месторождения всеми скважинами вскрыты напорные самоизливающиеся трещинные воды. Впервые эксплуатационные запасы термальных вод месторождения Ходжа-Оби-Гарм были утверждены ГКЗ СССР в 1957 г. Непосредственно сам республиканский курорт Ходжа-ОбиГарм функционирует с 1934 г. на 450 мест круглогодично. Бальнеотерапевтические процедуры обеспечиваются водолечебницей на 15 ванн, бассейном и пароэманаторием. Геотермальные воды месторождения Ходжа-Оби-Гарм используется для горячего водоснабжения и теплофикации всего санаторно-курортного комплекса [19].

\section{Химический состав воды}

Результаты проведенных исследований указывают на то, что по химическому составу термальные воды месторождения Ходжа-Оби-Гарм относятся к маломинерализованным (до 450 мг/л) хлоридно-сульфатно-гидрокарбонатным натриевым кремнистым водам с высокой щелочностью ( $\mathrm{pH}$ до
$9,18)$ и высокой температурой $\left(63,5-93{ }^{\circ} \mathrm{C}\right)[3,6$, $19,25]$.

Во многих скважинах среди анионов превалирует $\mathrm{HCO}_{3}{ }^{-}\left(\mathrm{CO}_{3}{ }^{2-}\right)$ ион, однако содержание сульфатиона в некоторых скважинах может достигать значительных концентраций. Основным катионом является $\mathrm{Na}^{2+}$, содержание которого доходит до 100 мг/л, в то время как содержание $\mathrm{Ca}^{2+}$ колеблется от 6 до $15 \mathrm{мг/л,} \mathrm{K}^{+}$не превышает 9 мг/л, а $\mathrm{Mg}^{2+}$ - не более $1 \mathrm{мг} /$ л. Помимо карбонатных ионов $\left(\mathrm{HCO}_{3}^{-}\right.$и $\left.\mathrm{CO}_{3}{ }^{2-}\right)$ в достаточно высоких количествах присутствуют хлор (до $55 \mathrm{мг/л)} \mathrm{и} \mathrm{сульфат-}$ ион (до 40 мг/л) [3, 6, 19, 25].

На рис. 3 представлена диаграмма Пайпера, иллюстрирующая химический состав термальных вод месторождения Ходжа-Оби-Гарм. Диаграмма построена по ретроспективным данным химического анализа проб термальных вод, которые были отобраны авторами на Ходжа-Оби-Гарм в 2014-2015 гг [3], а также по данным производственных отчетов.

Наличие борной кислоты составляет $\left(\mathrm{H}_{3} \mathrm{BO}_{3}\right)$ 6 мг/л. Исследуемые термы богаты фтором, концентрации которого достигают 18 мг/л [3]. Среднее содержание макрокомпонентов термальных вод месторождения Ходжа-Оби-Гарм приведено в табл. 1.

Содержание фтора в исследованных термах достаточно хорошо коррелирует с карбонатными ионами, но плохо с сульфатами. Кроме того, наблюдается положительная корреляция содержаний $\mathrm{F} \mathrm{c}$ содержанием $\mathrm{SiO}_{2}$ и температурой. Это, возможно, свидетельствует об идентичности источников фтоpa, кремния и натрия. Наиболее вероятно, данные компоненты поступают в водный раствор в результате гидролиза алюмосиликатных минералов [3, 4]. И чем более длительным является растворение материнского минерала, тем больше фтора поступает в водный раствор. $K$ тому же наблюдается достаточно высокое содержание кремнекислоты, которое составляет от 85,6 до 147 мг/л.

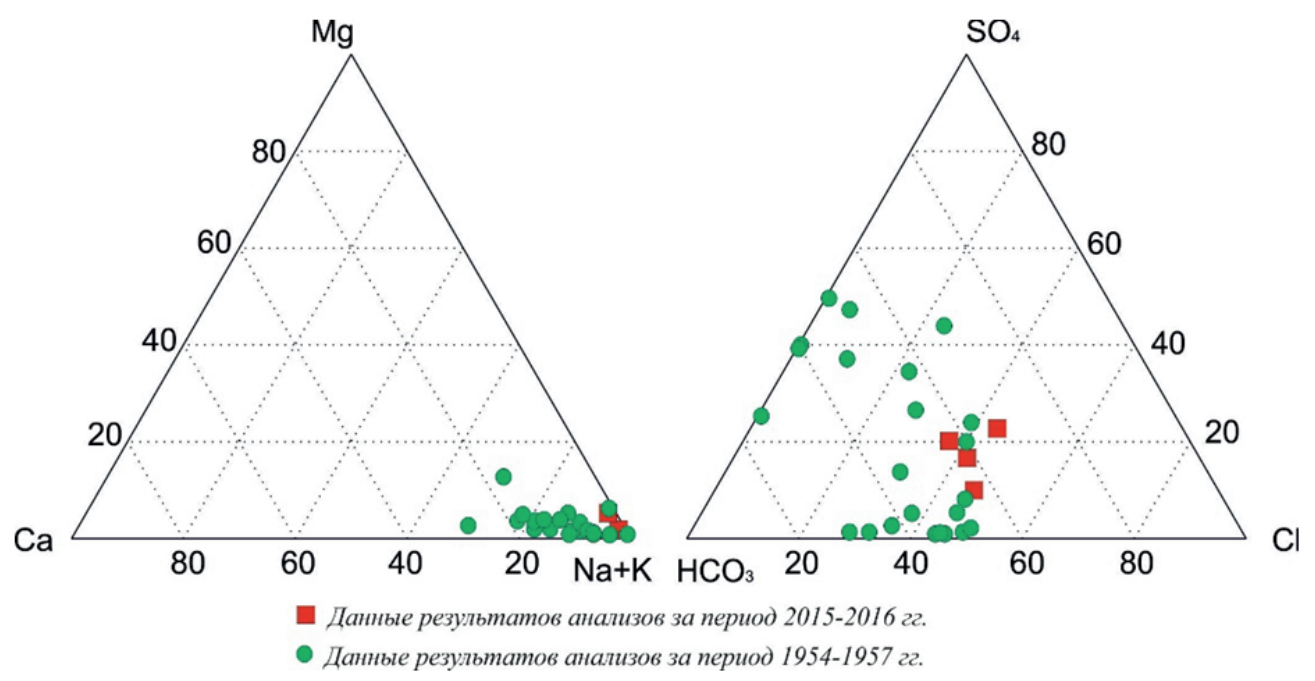

Рис.3. Тройная диагралма хилического состава терлальных вод месторождения Ходжа-Оби-Гарм

Fig. 3. Triple diagram of chemical composition of the thermal waters of the Khoja-Obi-Garm field 
Таблииа 1. Средние содержания микроэлементов в термальных водах месторождения Ходжа-Оби-Гарм (мкг/л)

Table 1. Average contents of microelements in thermal waters of the Khodja-Obi-Garm field ( $\mu \mathrm{g} / \mathrm{l})$

\begin{tabular}{|c|c|c|c|c|}
\hline \multirow{2}{*}{$\begin{array}{c}\text { Химические } \\
\text { элементы } \\
\text { Chemical } \\
\text { elements }\end{array}$} & \multicolumn{2}{|c|}{$\begin{array}{c}\text { Скважина } \\
\text { Well }\end{array}$} & $\begin{array}{c}\text { Среднее содержание } \\
\text { по месторождению } \\
\text { (понным отчета [27])** }\end{array}$ & $\begin{array}{c}\text { Зона } \\
\text { Average content } \\
\text { of the deposit (according } \\
\text { to the report [27])*** } \\
\text { Hypergenesis } \\
\text { zone [12] }\end{array}$ \\
\hline $\mathrm{Be}$ & 0,48 & 0,58 & 1,5 & 0,19 \\
\hline $\mathrm{Sc}$ & 0,09 & 0,06 & н.д/n.d. & 0,17 \\
\hline $\mathrm{V}$ & 0,17 & 0,08 & 1,3 & 1,34 \\
\hline $\mathrm{Cr}$ & 0,11 & 0,07 & 1,6 & 3,03 \\
\hline $\mathrm{Mn}$ & 2,53 & 4,11 & 3,1 & 54,5 \\
\hline $\mathrm{Co}$ & 0,04 & 0,01 & н.д/n.d. & 0,39 \\
\hline $\mathrm{Ni}$ & 0,42 & 0,07 & 1 & 3,58 \\
\hline $\mathrm{Cu}$ & 1,45 & 0,85 & 1 & 5,58 \\
\hline $\mathrm{Zn}$ & 1,8 & 1,6 & 5,1 & 41,4 \\
\hline $\mathrm{Ga}$ & 6,19 & 5,02 & н.д/n.d. & 0,37 \\
\hline $\mathrm{As}$ & 5,31 & 4,96 & н.д/n.d. & 1,46 \\
\hline $\mathrm{Se}$ & 0,12 & 0,11 & н.д/n.d. & 0,72 \\
\hline $\mathrm{Ag}$ & 0,035 & 0,003 & 0,91 & 0,26 \\
\hline $\mathrm{Cd}$ & 0,04 & 0,03 & н.д/n.d. & 0,24 \\
\hline $\mathrm{Ba}$ & 1,6 & 1,3 & 3,4 & 18,3 \\
\hline $\mathrm{Pb}$ & 3,34 & 0,28 & 1,83 & 2,97 \\
\hline $\mathrm{Li}$ & 991 & 953 & н.д/n.d. & 13 \\
\hline $\mathrm{Al}$ & 122 & 77 & 39 & 226 \\
\hline $\mathrm{Rb}$ & 116 & 111 & н.д/n.d. & 1,86 \\
\hline $\mathrm{Sr}$ & 168 & 160 & 78 & 183 \\
\hline $\mathrm{Cs}$ & 219 & 211 & н.д/n.d. & 0,26 \\
\hline $\mathrm{Fe}$ & 104 & 79 & 36,8 & 481 \\
\hline
\end{tabular}

Примечания: * - результаты, полученные методом ИСП-МС, ** - данные спектрального анализа, н.д-нет определений

Notes: * - results obtained by the ISP-MS, **-spectral analysis data, n.d. - no data

Содержание углекислоты свободной $\left(\mathrm{CO}_{2}\right)$ варьирует от 2 до 6 мг/л, а сероводорода $\left(\mathrm{H}_{2} \mathrm{~S}\right)$ содержится 3,54 мг/л. Установлена практически прямая зависимость между содержанием в растворе натрия и метакремниевой кислоты, что также говорит об одном минеральном источнике для данных компонентов (предположительно это натриевый полевой шпат - альбит, основной породообразующий минерал водовмещающих горных пород). Расчет форм нахождения основных ионов в растворе показал, что катионы до 99 \% находятся в ионной форме [3].

Оценивая вклад основных ионов в минерализацию, становиться очевидным, что основными компонентами, обеспечивающими минерализацию вод, являются: натрий, калий, кремний, хлор и фтор ионы, сульфат-ион и карбонатные ионы.

По микрокомпонентному составу термальных вод среди сидерофильной группы содержатся незначительные концентрации таких элементов, как железо $(68,8-139,6$ мкг/л), марганец $(1,18-7,04$ мкг/л), кобальт (0,013-0,039 мкг/л), никель (0,07-0,44 мкг/л). Среди халькофильных элементов присутствует медь $(0,4-2,2$ мкг/л), цинк $(0,8-2,3$ мкг/л), галлий $(3,9-7,2$ мкг/л), мышьяк $(4,6-5,34$ мкг/л), селен $(0,04-0,199$ мкг/л), серебро $(0,002-0,068$ мкг/л), кадмий $(0,029-0,047$ мкг/л) и свинец $(0,12-5,49$ мкг/л)
[3]. Среди литофильных элементов обнаружены концентрации лития $(0,9-1,03$ мг/л), рубидия (107,3-122,6 мкг/л), стронция (151,7-169,2 мкг/л), цезия $(204-231$ мкг /л) и аллюминия $(0,48-126,5$ мкг/л). По сравнению со средними значениями кларков в подземных водах зоны гипергенеза, для данного месторождения можно выделить повышенные концентрации $\mathrm{Be}, \mathrm{Ga}, \mathrm{Pb}, \mathrm{Cs}$, As.

Концентрации марганца составляют от 1,18 до 4,11 мкг/л, а концентрации ванадия, хрома и бария очень низкие и не превышают единичных значений в мкг/л. Содержание бора невелико - от 0,31 до 0,34 мг/л. Соотношение B/Cl составляет 0,006, что практически в четыре раза ниже, чем бор-хлорное отношение в морской воде (где оно равно $\left.2,4 \cdot 10^{4}\right)$. Это практически на порядок ниже, чем в углекислых водах Памира, и почти совпадает с показателем $\mathrm{B} / \mathrm{Cl}(0,04-0,007)$ в термальных источниках областей активного вулканизма [3]. Соотношение $\mathrm{Cl} / \mathrm{Br}$ равно 257 , что очень близко по значению к морским водам (293). Соотношение $\mathrm{Li}: \mathrm{Rb}: \mathrm{Cs}$ составляет 100:12:23, это несколько выше, чем в термальных водах Камчатки, Li:Rb:Cs=100:9:10 $[3,6,25,28]$.

Термальные воды месторождения Ходжа-ОбиГарм обогащены радоном - его концентрация составляет 22 нКи/л (814 Бк/л), и характеризуются слабой радиоактивностью, что связанно с условиями их формирования и циркуляции. Повсеместно, в термальных водах, формирующихся в осадочных карбонатных и песчано-глинистых породах, содержание радона обычно колеблется в пределах 1-3 нКи/л (37-111 Бк/л), в то время как термальные источники, локализованные в массивах кристаллических пород, содержат радона до 20 нКи/л (740 Бк/л). Столь высокие содержания $\mathrm{Ra}$ обнаружены в водах месторождений Белокуриха, Рахмановское, Копал-Арсан, Ак-Су, Гармчашма, на Хахдаре и др. [2, 3, 5-7, 10, 24].

Установлено, что накопление радона в термальных водах зависит не только от типа водовмещающих пород, но и от эманирующей способности горных пород, размеров трещин и скорости движения самих вод. При вскрытии скважинами зон и очагов повышенных концентраций радия на ряде месторождений были получены более радиоактивные воды, чем те, которые наблюдались при естественных выходах (Цхалтубо, Белокуриха, Ходжа-ОбиГарм и др.). Стоит отметить, что радиоактивность вод является одним из бальнеологических компонентов, определяющих лечебное значение слабоминерализованных терм, поэтому при оценке их терапевтического значения необходимо учитывать концентрации в них радона $[2,3,9,16,26]$.

\section{Химический состав водовмещающих пород}

Геохимический состав водовмещающих пород территории исследований, в пределах которой формируются ресурсы терм, несомненно, оказывает влияние на их химический облик. Водовмещающие породы представлены гранитами (образцы 
№ 1, 2), плагиогранитами (образец № 3) и гранодиоритами (образец № 4). Гранитные породы, сложенные преимущественно щелочными полевыми шпатами (до 90 \%), представлены двумя генерациями, отличающимися как по цвету (розоватокрасный - I тип (рис. 4) и светло-розовый - II тип), так и по содержанию кварца.

Основными минералами гранитов являются калий натриевый полевой шпат (90-95 мас. \%), плагиоклаз (до 10 мас. \% ), кварц (25-35 мас. \%) и биотит (3-10 мас. \% ). В качестве вторичного минерала диагностированы незначительные выделения карбонатов редкоземельных элементов. КПШ представлен ортоклазом с небольшим содержанием натрия (до 0,36 мас. \% ) и бария (до 0,75 мас. \% ВаO). Плагиоклазы являются практически чистыми альбитами с незначительной примесью кальциевой компоненты (не более 1,5 мас. \% CaO). Иногда содержат изоморфную примесь калия (до 0,3 мас. \%). В качестве акцессорных минералов часто диагностируются: ортит $(\mathrm{Ca}, \mathrm{Ce}, \mathrm{La}, \mathrm{Y})_{2}(\mathrm{Al}, \mathrm{Fe})_{3}\left(\mathrm{SiO}_{4}\right)_{3}(\mathrm{OH})$, торит $\left(\mathrm{ThSiO}_{4}\right)$, апатит, циркон, сфен.

Плагиогранит сложен КПШ (40-45 мас. \%), плагиоклазом (40-45 мас. \%), кварцем (до 40 мас. $\%$ ), биотитом (до 10 мас. \% ). Очень часто наблюдаются вторичные карбонаты, представленные практически чистым кальцитом, иногда с небольшой примесью железа. Используя микрозондовый анализ, удалось диагностировать большое количество зерен карбонатов, концентрирующих РЗЭ и иттрий. Вторичные железистые выделения представлены лепидокрокитом.

Основными минералами гранодиорита являются КПШ (до 60 мас. \% ), плагиоклаз (до 60 мас. \% ), кварц (20-25 мас. \% ) и биотит (до 10 мас. \%). Карбонаты и гидроокислы железа встречаются в незначительных количествах и являются вторичными минералами.

Химический состав водовмещающих пород представлен в табл. 2. Полученные результаты показывают, что в исследованных водовмещающих породах наблюдается дефицит натрия, поскольку он не образует самостоятельных минеральных фаз, а входит в структуру калиевого полевого шпата или калиево-натриевого полевого шпата. В целом водовмещающие породы являются щелочными.

Таблища 2. Химический состав водовмещающих пород месторождения Ходжа-Оби-Гарм

Table 2. Chemical composition of the water-bearing rocks of the Khoja-Obi-Garm field

\begin{tabular}{|c|c|c|c|c|c|c|c|c|c|}
\hline \multirow{2}{*}{$\begin{array}{c}\text { Oбразец } \\
\text { Sample }\end{array}$} & \multicolumn{3}{|c|}{ Макрокомпоненты, мас. \% /Macrocomponents, wt. \% } \\
\cline { 2 - 11 } & $\mathrm{SiO}_{2}$ & $\mathrm{TiO}_{2}$ & $\mathrm{Al}_{2} \mathrm{O}_{3}$ & $\mathrm{Fe}_{2} \mathrm{O}_{3}$ обш & $\mathrm{MnO}$ & $\mathrm{Mg} 0$ & $\mathrm{CaO}$ & $\mathrm{Na}_{2} \mathrm{O}$ & $\mathrm{K}_{2} \mathrm{O}$ \\
\hline 1 & 66,23 & 0,43 & 14,81 & 2,63 & 0,05 & 0,18 & 3,63 & 2,63 & 5,73 \\
\hline 2 & 73,01 & 0,29 & 13,51 & 2,45 & 0,02 & 0,67 & 0,88 & 2,46 & 5,76 \\
\hline 3 & 68,61 & 0,47 & 14,14 & 3,97 & 0,06 & 1,33 & 2,07 & 2,79 & 4,73 \\
\hline 4 & 65,42 & 0,54 & 14,65 & 4,36 & 0,06 & 1,47 & 2,86 & 2,94 & 4,79 \\
\hline
\end{tabular}

Содержание кальция в породах также невелико и не превышает 3,63 мас. \% . Скорее всего, невысокие концентрации кальция в породе вызваны полным отсутствием первичных кальцийсодержащих минералов. Были обнаружены только незначительные выделения вторичного карбоната, скорее всего, гидротермально образованного, который заполняет трещины в породах.

Проведенные исследования выявили повышенные содержания в водовмещающих породах месторождения фтора (до 17 мг/л). Основным фторсодержащим минералом является апатит, который часто диагностируется в виде удлиненных зерен в основной массе породы. Несмотря на многолетние исследования, вопрос об источниках фтора в термальных водах до сих пор остается спорным, хотя в настоящее время подавляющее большинство исследователей склоняются к поступлению фтора из вмещающих пород $[3,4]$. Мы также склоняемся к данной точке зрения. Полученные нами результаты свидетельствуют, что водовмещающие породы термального поля Ходжа-Оби-Гарма содержат многочисленные вкрапления фторсодержащих минералов (апатит, иногда, сфен). Также в термальных водах месторождения наблюдается положительная корреляция содержаний фтора с содержанием $\mathrm{SiO}_{2}$ и температурой.
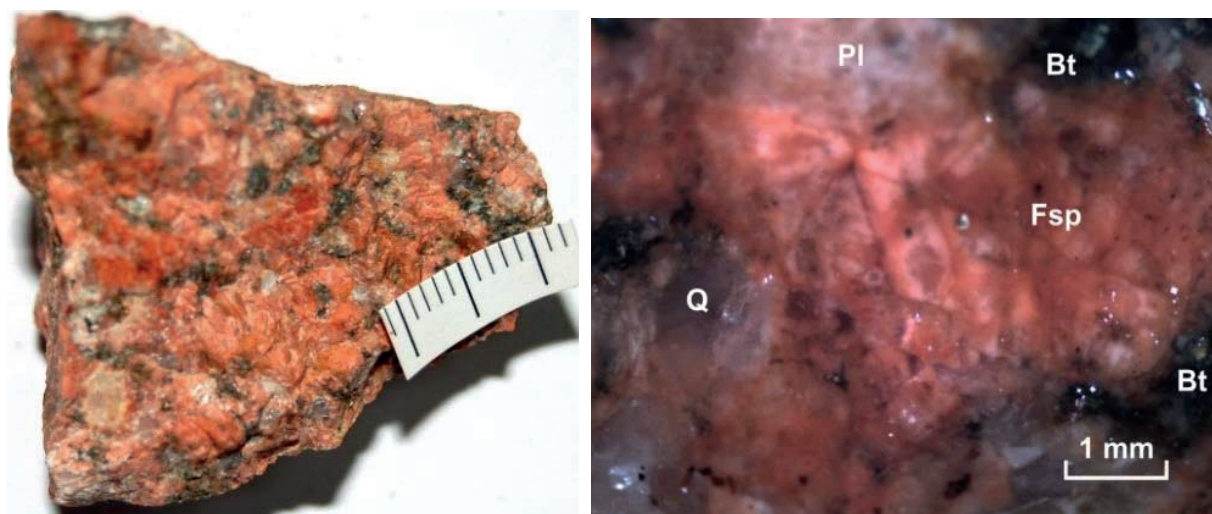

Pис.4. Массивная текстура гранита I генерации (слева). Минеральный состав: биотит (Bt)-квари (Q)-плагиоклаз (Pl)-калишпатовая ассоциация (Fsp) в граните (справа)

Fig. 4. Massive texture of alkalian-feldspar granite of the I generation (left). Mineral composition: biotite (Bt)-quartz (Q)-plagioclase (Pl)-feldspar association (Fsp) in granite (right) 

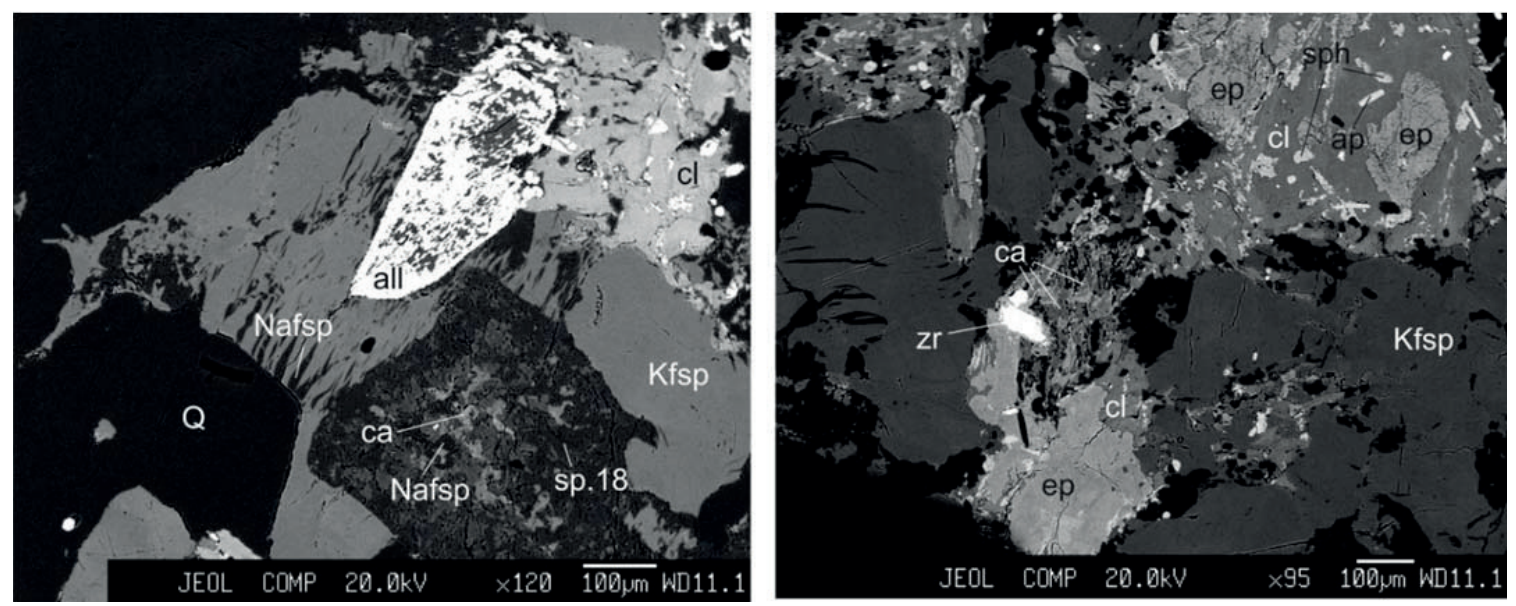

Pис. 5. Минеральный состав водовмещающих пород месторождения Ходжа-Оби-Гарм. Фотография получена на микрозонде Јеоl, ЈХА8100 (ДВГИ ДВО РАН). Слева фотография с увеличением х120. Справа фотография с увеличением х95. Аббревиатура: $Q-$ квари; Nafsp - калинатриевый полевой шпат; Kafsp - калиевый полевой шпат; all - алланит; ap - anaтит; ер - эnидот; clхлорит; са - кальцит; sp - серпофит; sph-сфен; $z r-$ циркон

Fig. 5. Mineral composition of water-bearing rocks of the Khoja-Obi-Garm field. The photograph was obtained on a microprobe Jeol, JXA-8100 (FGI FEB RAS). On the left there is a photograph with an increase of $x 120$. Right photo with an increase of $x 95$. Abbreviation: $Q-$ Quartz; Nafsp-calinatric feldspar; Kafsp-potassium feldspar; all-allanitis; ap-apatite; ep-epidote; cl-chlorite; ca-calcite; spserpofit; sph-sphene; zr-zircon

Таблица 3. Содержание микрокомпонентов в водовмещающих породах месторождения Ходжа-Оби-Гарм (лас.\%)

Table 3. $\quad$ Content of rare elements in the water-bearing rocks and thermal waters of the Khoja-Obi-Garm field (wt.\%)

\begin{tabular}{|c|c|c|c|c|c|}
\hline \multirow{2}{*}{$\begin{array}{c}\text { Микроэлементы } \\
\text { Microelements }\end{array}$} & \multicolumn{4}{|c|}{ Образец/Sample } & \multirow{2}{*}{$\begin{array}{c}\text { Земная кора } \\
\text { Earth's crust [21] }\end{array}$} \\
\hline & 1 & 2 & 3 & 4 & \\
\hline $\mathrm{Be}$ & \begin{tabular}{|l|}
3,057 \\
\end{tabular} & 1,57 & 4,25 & 2,315 & 3,8 \\
\hline Sc & \begin{tabular}{|l|}
16,93 \\
\end{tabular} & 12,97 & 20,2 & $\begin{array}{ll}18,03 \\
\end{array}$ & 10 \\
\hline $\mathrm{V}$ & \begin{tabular}{|l|}
18,09 \\
\end{tabular} & 23,52 & 41,6 & 40,3 & 90 \\
\hline $\mathrm{Cr}$ & 11,05 & 17,36 & 32,95 & 27,64 & 83 \\
\hline $\mathrm{Co}_{0}$ & \begin{tabular}{|l|}
2,158 \\
\end{tabular} & 4,189 & \begin{tabular}{|l|l|}
7,141 \\
\end{tabular} & $\begin{array}{l}6,784 \\
\end{array}$ & 18 \\
\hline $\mathrm{Ni}$ & 5,763 & 8,966 & $\mid 12,51$ & 12,7 & 58 \\
\hline $\mathrm{Cu}$ & 13,883 & 6,51 & 10,65 & 9,48 & 47 \\
\hline $\mathrm{Zn}$ & 24,72 & 31,22 & \begin{tabular}{|l|l|}
57,39 \\
\end{tabular} & $\begin{array}{l}59,32 \\
\end{array}$ & 83 \\
\hline $\mathrm{Ga}$ & \begin{tabular}{|l|}
21,13 \\
\end{tabular} & 15,14 & \begin{tabular}{|l|l|}
18,57 \\
\end{tabular} & $\begin{array}{l}19,86 \\
\end{array}$ & 19 \\
\hline As & \begin{tabular}{|l|}
2,269 \\
\end{tabular} & 1,179 & \begin{tabular}{|l|}
2,575 \\
\end{tabular} & 1,347 & 1,7 \\
\hline $\mathrm{Rb}$ & 158,8 & 137 & 141 & 116,3 & 150 \\
\hline $\mathrm{Sr}$ & 150,5 & 270,4 & \begin{tabular}{|l|}
216,2 \\
\end{tabular} & 280 & 340 \\
\hline $\mathrm{Zr}$ & 329,9 & $\begin{array}{l}176,6 \\
\end{array}$ & \begin{tabular}{|l|}
180,5 \\
\end{tabular} & 134 & 170 \\
\hline $\mathrm{Nb}$ & 12,1 & 5,923 & $\mid 14,11$ & $\begin{array}{l}7,422 \\
\end{array}$ & 20 \\
\hline Mo & \begin{tabular}{|l|l|}
0,744 \\
\end{tabular} & \begin{tabular}{|l}
0,2563 \\
\end{tabular} & \begin{tabular}{|l|}
0,606 \\
\end{tabular} & 0,366 & 1,1 \\
\hline $\mathrm{Cd}$ & 0,2667 & 0,1359 & 0,1547 & 0,1056 & 0,13 \\
\hline Sn & \begin{tabular}{|l|}
3,227 \\
\end{tabular} & 2,554 & 10,1 & 4,679 & 2,5 \\
\hline $\mathrm{Cs}$ & 7,2 & 2,0113 & 7,9575 & 5,465 & 3,7 \\
\hline $\mathrm{Ba}$ & 511,20 & 1099,00 & 648,70 & 1378,00 & 650 \\
\hline $\mathrm{Hf}$ & 11 & 6,287 & 5,903 & 4,963 & 1 \\
\hline $\mathrm{Ta}$ & 1,167 & 0,5949 & $\mid$\begin{tabular}{|l|}
1,701 \\
\end{tabular} & 0,6168 & 2,5 \\
\hline W & \begin{tabular}{|l|}
2,656 \\
\end{tabular} & 0,8504 & \begin{tabular}{|l|l|}
1,543 \\
\end{tabular} & 1,614 & 1,3 \\
\hline $\mathrm{Pb}$ & 14,34 & 18,94 & \begin{tabular}{|l|}
22,48 \\
\end{tabular} & 14,41 & 16 \\
\hline Th & 69,6 & 92,49 & \begin{tabular}{|l|}
61,83 \\
\end{tabular} & 10,6 & 13 \\
\hline $\mathrm{U}$ & 12,02 & 20,57 & \begin{tabular}{|l|}
9,088 \\
\end{tabular} & 2,31 & 2,5 \\
\hline
\end{tabular}

Химический состав основных породообразующих минералов, выполненный на микрозонде (рис. 5), показал, что породообразующие минералы представлены в основном кварцем, калиевым полевым шпатом (КПШ) и рядом плагиоклазов (от альбита до анортита). Среди акцессорных минералов часто встречаются: циркон, апатит, карбонаты редкоземельных элементов. Метаморфизм пород выражен в хлоритизации, карбонатизации и эпидотизации по альбиту и КПШ.

Валовый химический состав водовмещающих пород демонстрирует высокие содержания следующих микрокомпонентов (мкг/кг): рубидия (116-159), стронция $(150-280)$, циркония (134-330), бария (511-1378) и др. (табл. 3). Кроме того, выявлены повышенные содержания тория (до 92 мкг/кг) и урана (до 20 мкг/кг).

Широко известно, что в целом в гидросфере содержание радиоактивных элементов ничтожно мало, однако исследуемые воды характеризуются значительными содержаниями урана и тория. Для выявления источников этих элементов представлялось весьма интересно провести детальное исследование распределения урана и тория в водовмещающих породах.

Микрозондовые исследования показали, что основным минералом-концентратором Th и $\mathrm{U}$ является циркон, содержащий до $9,5 \%$ Th и $6,6 \%$ U. Также были диагностированы зерна торита $\left(\mathrm{ThSiO}_{4}\right)$ с содержанием $\mathrm{Th}$ до $47 \%$.

Предварительные результаты показывают, что несомненным источником радиоактивных элементов в термальных водах Ходжи-Оби-Гарма являются водовмещающие породы, которые, взаимодействуя с водами при высоких температурах, paстворяются и поставляют в воду данные элементы.

По микрокомпонентному составу водовмещающие породы месторождения термальных вод Ходжа-Оби-Гарм обогащены скандием, галлием, барием, торием и ураном. 


\section{Взаимодействие воды с породой}

Для количественной оценки интенсивности водной миграции химических элементов был использован коэффициент водной миграции $\left(K_{\mathrm{Bu}}\right)$, который определялся по формуле [9]:

$$
K_{\mathrm{BM}}=\frac{m_{x} \cdot 100}{M \cdot n_{x}},
$$

где $m_{x}$ - содержание элемента в воде мкг/л; $M$ минерализация воды, мкг/л; $n_{x}$ - содержание элемента в водовмещающей породе, \% . Этот коэффициент был предложен А.И. Перельманом и основывается на идеях Б.Б. Полынова о неравномерном выносе химических элементов из горных пород. Из формулы можно понять, что чем выше коэффициент водной миграции, тем сильнее элемент способен выщелачиваться из вмещающих горных пород.

Также были вычислены коэффициенты интенсивности осаждения $\left(K_{0}\right)$ и коэффициенты геохимической подвижности $\left(K_{\mathrm{n}}\right)$ [29], значения которых приведены в табл. 4.

Таблица 4. Геохимическая подвижность элементов месторождения Ходжа-Оби-Гарм

Table 4. Geochemical mobility of elements of the Khoja-Obi-Garm field

\begin{tabular}{|c|c|c|c|c|c|c|c|}
\hline 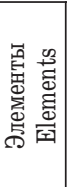 & 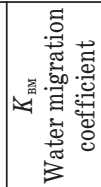 & 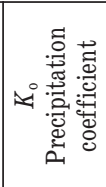 & 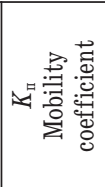 & 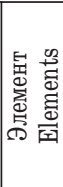 & 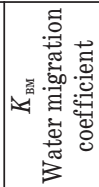 & 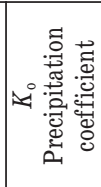 & 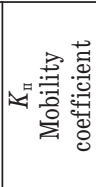 \\
\hline $\mathrm{Be}$ & 0,0611 & & & $\operatorname{Pr}$ & 0,0003 & & \\
\hline Sc & 0014 & 058 & 073 & $\mathrm{Nd}$ & 0,0004 & & \\
\hline Sc & 8 & & & $\mathrm{Sm}$ & 05 & & \\
\hline $\mathrm{V}$ & & & & & & & \\
\hline$U_{1}$ & & & & & & & \\
\hline Co & 15 & & & $\mathrm{~Tb}$ & 008 & & \\
\hline $\mathrm{Ni}$ & & & & 0 & & & \\
\hline $\mathrm{Cu}$ & & & & & & & \\
\hline 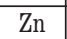 & & & & & & & \\
\hline 4 & & & & & & & \\
\hline As & & & & 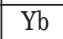 & & & \\
\hline $\mathrm{Rb}$ & 42 & 74 & 16 & T & & & \\
\hline $\mathrm{Sr}$ & 09 & 91 & & & & & \\
\hline $\mathrm{Y}$ & & & & Th & & & \\
\hline $\mathrm{Ca}$ & & & & & & & \\
\hline $\mathrm{Cs}$ &, 2485 & 345,2132 & 357,4617 & $\mathrm{Zr}$ & & & \\
\hline $\mathrm{Ba}$ & & & & 1010 & & & \\
\hline$\pi$ & & & & & & & \\
\hline $\mathrm{Ce}$ &, 00 &, 0259 & 0,0261 & $\bar{V}$ & 7,35 & 0,622 & 7 \\
\hline
\end{tabular}

Коэффициент интенсивности осаждения по аналогии с коэффициентом водной миграции определяется как отношение содержания элемента в растворе к его содержанию в продуктах, образованных в результате разрушения водой первичных пород. Таким образом, в отличие от $K_{\text {вм }}$ который характеризует относительный вынос элементов из горных пород, $K_{0}$ определяет относительную степень связывания элементов вторичными продуктами.
Геохимическая подвижность любого элемента определяется результирующим влиянием этих двух процессов. Ввиду этого подвижность элементов в условиях зоны гипергенеза можно оценить путём определения коэффициента геохимической подвижности $K_{\text {п }}$, который равен: $K_{\text {п }}=K_{\text {вм }}+K_{0}[29]$.

После проведенных расчетов можно выделить элементы, подвижность которых практически не изменяется, изменяется незначительно и изменяется более чем в два раза (табл. 4).

Уровень накопления (концентрирования) элементов в воде был оценен с использованием коэффициента концентрирования $\left(K_{\mathrm{r}}\right)$, который определяется по формуле $K_{\mathrm{K}}=C_{i} / C_{\phi}$, где $C_{i}$ - средняя концентрация химического элемента в данной выборке; $C_{\phi}-$ фоновое содержание этого элемента (рис. 6).

Проведенные расчеты показывают, что высоким уровнем накопления (с $K_{\mathrm{\kappa}}$ больше 10 ) обладают литий, галлий, рубидий, цезий и кремний. Ванадий, хром, марганец, кобальт, никель, цинк, серебро, барий и торий (уран) обладают низкой концентрирующей способностью $\left(K_{\mathrm{K}}\right.$ - менее 0,1$)$.

К группе редких элементов, которая включает рассеянные, редкоземельные и благородные элементы, как правило, относятся относительно малораспространенные элементы, с кларками преимущественно $<0,01 \%$ по массе [29-31]. На месторождении Ходжа-Оби-Гарм изучены эти элементы, среди которых превалируют: $\mathrm{Sc}, \mathrm{Ga}, \mathrm{Rb}, \mathrm{Cd}$, Th, U (табл. 5).

По среднему содержанию в термальных водах редкие элементы образуют последовательность: $\mathrm{Rb}>>>\mathrm{Ga}>>\mathrm{U}>\mathrm{Sc}>\mathrm{Cd}>\mathrm{Th} . \mathrm{B}$ водовмещающих породах последовательность иная: $\mathrm{Rb}>\mathrm{Th}>\mathrm{Ga}>\mathrm{Sc}>\mathrm{U}>>\mathrm{Cd}$. Все остальные элементы находятся в значительно меньших концентрациях.

Повышенное содержание $\mathrm{Rb}$ характерно практически для всех гидротерм в мире. Генезис его имеет дискуссионный характер: большинство исследователей считают, что Rb поступает в воду в результате выщелачивания водовмещающих пород, обогащенных этим элементом $[1,3,28,32]$.

Таблииа 5. Содержание редких элементов в водовлещающих породах $(2 / m)$ и терлальных водах (мкг/л) месторождения Ходжа-Оби-Гарм

Table 5. Content of rare elements in the water-bearing rocks and thermal waters of the Khoja-Obi-Garm field

\begin{tabular}{|c|c|c|c|c|c|c|}
\hline \multirow{2}{*}{$\begin{array}{c}\text { Компонент } \\
\text { Component }\end{array}$} & \multicolumn{3}{|c|}{$\begin{array}{c}\text { Водовмещающие породы } \\
\text { Water-bearing rocks }\end{array}$} & \multicolumn{2}{c|}{$\begin{array}{c}\text { Термальные воды } \\
\text { Thermal waters }\end{array}$} \\
\cline { 2 - 7 } & \multicolumn{3}{|c|}{ 0бразец/Sample } & \multicolumn{2}{c|}{ Скважина/Well } \\
\cline { 2 - 7 } & 1 & 2 & 3 & 4 & 7 & 16 \\
\hline $\mathrm{Sc}$ & 16,93 & 12,97 & 20,2 & 18,03 & 0,0891 & 0,07 \\
\hline $\mathrm{Ga}$ & 21,13 & 15,14 & 18,57 & 19,86 & 7,2142 & 6,18 \\
\hline $\mathrm{Rb}$ & 158,8 & 137 & 141 & 116,3 & 122,6 & 113,79 \\
\hline $\mathrm{Cd}$ & 0,27 & 0,14 & 0,15 & 0,11 & 0,047 & 0,03 \\
\hline $\mathrm{Th}$ & 69,6 & 92,49 & 61,83 & 10,6 & 0,03 & 0,01 \\
\hline $\mathrm{U}$ & 12,02 & 20,57 & 9,088 & 2,31 & 0,22 & 0,08 \\
\hline
\end{tabular}

В скальных породах месторождения $\mathrm{Rb}$ в основном входит в состав слюд и калиевых полевых 


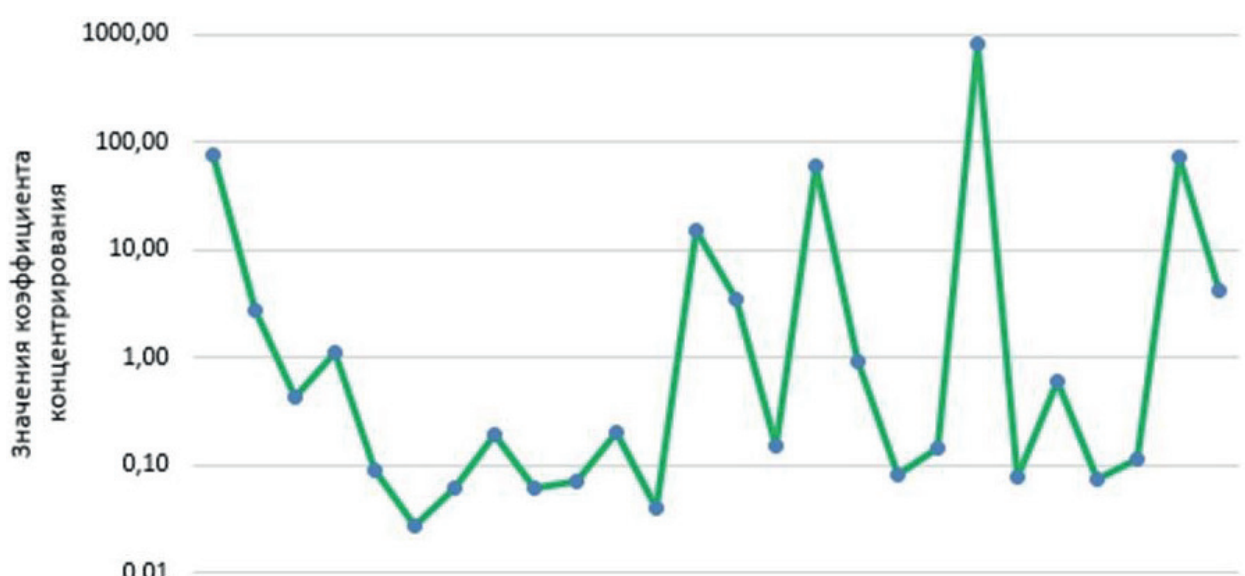

Li Be Al Sc V Cr Mn Fe Co Ni Cu Zn Ga As Se Rb Sr Ag Cd Cs Ba Pb Th U Si B

Puс. 6. Коэффициент кониентрирования микроэлементов в терлальных водах месторождения Ходжа-Оби-Гарл

Fig. 6. Concentration ratio of microelements in the thermal waters of the Khoja-Obi-Garm field

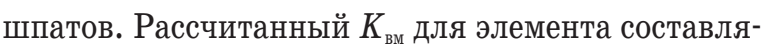
ет 0,26 , т. е. в данных условиях $\mathrm{Rb}$ не является сильным мигрантом.

Содержание Ga в водах находится в диапазоне значений $6,2-7,2$ мкг/л. В водовмещающих толщах концентрация элемента в целом соответствует его кларковому значению и составляет 15-21 г/т. Основными минералами-концентраторами Ga являются также основные породообразующие минералы (слюды и полевые шпаты). Во вторичной фазе количество $\mathrm{Ga}$ низкое $(0,07$ г/т).

Содержания U в водах месторождения низкие и варьируют в области 0,06-0,13 мкг/л. Основным минералом, содержащим диагностируемое количество элемента, является циркон (до 6,7 мас. \%). Установлено, что при высокой щелочности исследуемых термальных вод уран мигрирует главным образом в виде гидрокси-уранилов и карбонат-уранилов. Новообразованная вторичная фаза содержит U в незначительных количествах (до 1,2 г/т). Коэффициент водной миграции урана $\approx 0,0043$ показывает, что элемент является неподвижным мигрантом в данной геохимической обстановке. Коэффициент концентрации U низкий (около 0,11), однако он выше, чем у Th, но меньше, чем у Sc.

Концентрации Th в водах варьируют слабо и в среднем составляют $0,016 \mathrm{ppm}$. Столь низкие значения Th в воде, несмотря на высокие концентрации элемента (до 92 г/т) в водовмещающих породах, обусловлены физико-химическими свойствами элемента. Как известно, Тh является одним из наименее подвижных в процессе выщелачивания элементом [33], для примера растворимость $\mathrm{U}^{6+}$ в воде на три порядка выше, чем $\mathrm{Th}^{4+}$. Основным минералом концентратором тория является непосредственно торий (до 47 мас. \% Th), значительные количества данного элемента также диагностированы в цирконах (до 7 мас. \%) и монацитах (до 1,6 мас. \%). $K_{\text {вм }}$ для тория почти в два раза ниже, чем для урана.

Среднее содержание Sc в скальных породах месторождения более чем в три раза превышает кларк элемента в земной коре и составляет 17 г/т. Основной минеральной формой, концентрирующей элемент, является циркон (Sc до 0,6 мас. \%). В водах уровень элемента очень низкий и составляет 0,07-0,09 мкг/л, что характерно для столь щелочных вод. $K_{\text {вм }}$ скандия низкий $(0,0028)$, соответственно интенсивность водной миграции элемента очень слабая. Коэффициент концентрации составляет 1,09 .

Уровень концентрации $\mathrm{Cd}$ в скальных породах месторождения примерно равен кларку элемента в земной коре [5, 32]. Содержания в термальных водах еще на три порядка ниже $\left(C_{\mathrm{cp}} \approx 0,03\right.$ мкг/л). Кадмий имеет очень слабую интенсивность водной миграции, $K_{\text {вм }}$ составляет 0,0668 .

\section{Заключение}

По химическому составу термальные воды месторождения Ходжа-Оби-Гарм относятся к маломинерализованным (до 450 мг/л) хлоридно-сульфатно-гидрокарбонатным натриево-кремнистым водам. Воды обогащены фтором (до 18 мг/л), литием (до 1,03 мг/л), галлием (7,2 мкг/д), свинцом (до 5,5 мкг/л), мышьяком (до 5,7 мкг/л) и радоном (до 815 Бк/л) [2, 3, 6, 7, 19, 20, 24, 25].

Проведенные исследования показывают, что редкие элементы в скальных породах месторождения образуют в соответствии с их содержанием следующую последовательность: $\mathrm{Rb}>\mathrm{Th}>\mathrm{Ga}>\mathrm{Sc}>\mathrm{U}>>\mathrm{Cd}$. Термальные воды месторождения в значительной мере обогащены $\mathrm{Rb}$, который имеет наибольший среди редких элементов коэффициент водной миграции. Далее следуют Th и Ga, остальные элементы присутствуют в «следовых» количествах.

При движении из глубин к поверхности термальные воды интенсивно взаимодействуют с водовмещающими породами и растворяют их. Во время данного процесса происходит, предположительно, выщелачивание многих микрокомпонентов (La, $\mathrm{Rb}, \mathrm{Zr}, \mathrm{Ba}, \mathrm{Li}$ и др.) и концентрирование их в водах. 
Преимущественно натриевый состав вод определяется интенсивным растворением альбита, в то время как КПШ реагируют с раствором незначительно. Высокое содержание кремния в растворе

\section{СПИСОК ЛИТЕРАТУРЫ}

1. Арсанова Г.И. Происхождение термальных вод вулканических областей // Вулканология и сейсмология. - 2014. № 6. - С. 44-58.

2. Барабанов Л.Н., Дислер В.Н. Азотные термы СССР / отв. ред. д.г-м.н. В.В. Иванов. - М.: Геоминвод ЦНИИ КиФ, 1968. $120 \mathrm{c}$.

3. Замана Л.В. Фтор в азотных термах Забайкалья // Геология и геофизика. - 2000. -Т. 41. - № 11. - С. 1575-1580.

4. Плюснин А.М., Чернявский М.К., Посохова В.Ф. Условия формирования гидротерм Баргузинского Прибайкалья по данным микроэлементного и изотопного состава // Геохимия. 2008. - № 10. - С. 1063-1072.

5. Химический состав азотных термальных вод бальнеоклиматического курорта Ходжа-Оби-Гарм (Таджикистан) / А.Ю. Демонова, Н.А. Харитонова, А.В. Корзун, А.И. Сардоров, Г.А. Челноков // Вестник Московского университета. Серия 4. Геология. -2017 . - № 5. - С. 77-84.

6. Thermal waters at the western part of Pamir-Alay mountain system (Tajikistan) / A. Demonova, N. Kharitonova, I. Bragin, G. Chelnokov // $11^{\text {th }}$ International Hydrogeological Congress. Athens: National technic university of Athens, 2017. - V. 2. P. $165-173$.

7. Басков Е.А., Суриков С.Н. Гидротермы Земли. - Л.: Недра, 1989. - $243 \mathrm{c}$.

8. Кирюхин А.В., Шадрина С.В., Пузанков М.Ю. Моделирование термогидрогеохимических условий формирования продуктивных резервуаров в вулканогенных породах // Вулканология и сейсмология. - 2013. - № 2. - С. 90-104.

9. Перельман А.И. Геохимия элементов в зоне гипергенеза. - М.: Недра, 1972. - 288 c.

10. Плюснин А.М., Гунин В.И. Природные гидрогеологические системы, формирование химического состава и реакция на техногенное воздействие (на примере Забайкалья). - УланУдэ: Изд-во БНЦ СО РАН, 2001. - 137 с.

11. Чудаев 0.В. Состав и условия образования современных гидротермальных систем дальнего Востока России. - Владивосток: Дальнаука, 2003. - 216 с.

12. Hydrochemistry of low-temperature thermal water of Primorye region (Russia) and environmental implications / G. Chelnokov, I. Bragin, N. Kharitonova, B. Chelnokova // Water Research and Hydraulic Engineering. - 2015. - V. 3. - P. 98-201.

13. Grasby S.E., Hutcheon I., Krouse H.R. The influence of waterrock interaction on the chemistry of thermal springs in western Canada // Applied Geochemistry. - 2007. - V. 15. - P. 439-454.

14. Thermal-hydrodynamic-chemical (THC) modeling based on geothermal field data. Geothermics / A. Kiryuhin, T. Xu, K. Pruss, J. Apps, I. Slovtsov // Techonophysics. France. - 2004. - V. 33. P. 199-214.

15. Michard G. Behaviour of major elements and some trace elements (Li, Rb, Cs, Sr, Fe, Mn, W, F) in deep hot waters from granitic areas // Chemical geology. - 1990. - V. 89. - P. 117-134.

16. Кац В.Е. Природная радиоактивность геологической среды // Радиоактивность и радиоактивные элементы в среде обитания человека: материалы II Международной конференции. Томск: Изд-во ТПУ, 2004. - С. 549-557.

17. Gallois R.W. The formation of the hot springs at Bath Spa, UK // Geological Magazine. - 2007. - V. 144. - P. 741-747. обусловлено его поступлением при растворении плигиоклазов.

Работа выполнена при финансовой поддержке гранта РФФИ № 18-05-00445.

18. Разыков Б.Х. Особенности размещения и экономическая оценка минеральных вод Таджикистана. - Душанбе: Дониш, 2007. -99 c.

19. Баратов Р.Б. Геология и петрография района термальных источников Ходжа-Оби-Гарм. Отчет Ходжа-Оби-Гармской геологической партии по работам 1946 г. - Душанбе, 1946. - 64 с.

20. Демонова А.Ю., Харитонова Н.А. Методы определения и условия формирования химического состава термальных вод месторождения Ходжа-Оби-Гарм // Морские исследования и образование (MARESEDU-2017): Tруды VI Международной научно-практической конференции. - Тверь: 000 «ПолиПРЕСС», 2017. - C. 659-663.

21. Демонова А.Ю., Брагин И.В., Разыков Б.Х. Условия формирования термоминеральных вод южных отрогов Гиссарского хребта / / XXI Совещание по подземным водам Сибири и Дальнего Востока. - Новосибирск: Новосибирский государственный университет, 2018. - С. 166-172.

22. Демонова А.Ю., Харитонова Н.А., Сардоров А.И. Химический состав термальных вод курорта Ходжа-Оби-Гарм (Таджикистан) // Санаторно-курортное лечение: Материалы III Международного конгресса. - М., 2017. - С. 30.

23. Шапар А.А., Туев В.Г. Результаты разведочных гидрогеологических работ на месторождении термальных вод Ходжа-ОбиГарм. Т. I. Комплексная геологическая экспедиция. - Душанбе: ТаджикГИИНТИЗ, 1967. - 96 с.

24. Demonova A., Kharitonova N., Sardorov A. Chemical composition of thermal waters of Khoja-Obi-Garm Spa // 42 World congress of the international society of medical hydrology and climatology. - Moscow, 2017. - P. 39 .

25. Гидрогеология CCCP. T. XLI. Таджикская ССР / под ред. B.C. Самариной. - М.: Недра, 1972. - 472 c.

26. Виноградов А.П. Среднее содержание химических элементов в главных типах изверженных горных пород земной коры // Геохимия. - 1962. - № 7. - С. 555-571.

27. Геохимические особенности распределения основных и редкоземельных элементов в Паратунской и Большебанной гидротермальных системах Камчатки / О.В. Чудаев, Г.А. Челноков, И.В. Брагин, Н.А. Харитонова, С.Н. Рычагов, А.А. Нуждаев, И.А. Нуждаев // Тихоокеанская геология. - 2016. - Т. 35. № 6. - С. 102-119.

28. Шварцев С.Л. Гидрогеохимия зоны гипергенеза. - М.: Недра, 1998. -287 c.

29. Shvartsev S.L. Geochemistry of Fresh Groundwater in the Main Landscape Zones of the Earth // Geochemistry International. 2008. - V. 46. - № 13. - P. 1-114.

30. Hydrogeology of thermal waters in Viterbo area, central Italy / V. Piscopo, M. Barbieri, V. Monetti, G. Pagano, S. Pistoni, E. Ruggi, D. Stanzione // Hydrogeology Journal. - 2006. V. 14. - P. 1508-1521.

31. Шварцев С.Л. Фундаментальные механизмы взаимодействия в системе вода-горная порода и ее внутренняя геологическая эволюция // Литосфера. - 2008. - № 6. - С. 3-24.

32. Смыслов А.А. Уран и торий в земной коре. - Л.: Недра, 1974. 231 c.

Поступила 18.10.2018 2. 


\section{Информация об авторах}

Демонова А.Ю., ведущий инженер кафедры гидрогеологии Геологического факультета Московского государственного университета им. М.В. Ломоносова.

Харитонова H.А., доктор геолого-минералогических наук, профессор кафедры гидрогеологии Геологического факультета Московского государственного университета им. М.В. Ломоносова; главный научный сотрудник лаборатории геохимии гипергенных процессов Дальневосточного геологического института Дальневосточного отделения Российской академии наук.

Брагин И.В., кандидат геолого-минералогических наук, старший научный сотрудник лаборатории геохимии гипергенных процессов Дальневосточного геологического института Дальневосточного отделения Российской академии наук.

Челноков Г.A., кандидат геолого-минералогических наук, ведущий научный сотрудник, заведующий отделом и руководитель лаборатории геохимии гипергенных процессов Дальневосточного геологического института Дальневосточного отделения Российской академии наук.

Тарасенко И.А., доктор геолого-минералогических наук, заместитель директора по научной работе Дальневосточного геологического института Дальневосточного отделения Российской академии наук. 
UDC 551.234. 556.314

\title{
MICROCOMPONENT COMPOSITION OF LOW-MINERALIZED NITROGEN THERMES OF THE GISSAR RIDGE (PAMIR-ALAY MOUNTAIN SYSTEM)
}

\author{
Anna Yu. Demonova',
} danna1985@yandex.ru

Natalia A. Kharitonova1,2, tchenat@mail.ru

Ivan V. Bragin²,

bragin_ivan@mail.ru

Georgiy A. Chelnokov², geowater@mail.ru

Irina A. Tarasenko², tarasenko_irina@mail.ru

1 Lomonosov Moscow State University, 1, Lenin Hills, Moscow, 119991, Russia.

2 Far Eastern Geological Institute of the Far-Eastern Branch of the Russian Academy of Sciences, 159, 100 let Vladivostoku avenue, Vladivostok, 690022, Russia.

The relevance of the research is caused by the need for reasonable use of natural resources and thermomineral waters, in particular the unique balneoclimatic resort of Khoja-Obi-Garm, located in the central part of the spurs of the southern slope of the Gissar Ridge. The investigation of the microcomponent composition of these waters remains one of the most pressing problems for the study.

The main aim. The study of these waters began in the middle of the twentieth century, but the microcomponent composition of the waters is still poorly understood. The main aim of this work is a detailed study of distribution of chemical elements in thermal waters of the Khoja-Obi-Garm field, as well as identification of sources of their supply, mechanisms and factors of mobilization and fractionation. Objects of the research are groundwater and water-bearing rocks of the low-mineralized thermal waters of Khoja-Obi-Garm, which is confined to the Pamir-Alai mountain system (Tajikistan).

Methods. The results of chemical analyzes of the water phase and water-bearing rocks are presented in the analytical units of the Far Eastern Geological and Far Eastern Oceanological Institutes of the Far Eastern Branch of the Russian Academy of Sciences. The main cations and anions of thermal waters were determined by the method of liquid ion chromatography (HPLC-10AVp, SHIMADZU), and micro- and scattered elements were analyzed using plasma-optical emission spectrometry (ICP-AES, Plasmaquant-110) and inductive plasma mass spectroscopy (ICP -MS, Agilent 7500C). For more complete understanding of the processes taking place in the water-rock system, the following programs were used: AQUACHEM 5.1, WATERQ4F, PHREEQC. The macrophotographs of the water-bearing rocks were performed with a Nikon digital camera, and petrographic studies were performed using a Leica-E stereoscopic microscope equipped with a digital camera. The content of the main elements in the samples was determined by atomic emission spectrometry on an iCAP 7600 Duo (Thermo Scientific) spectrometer and by inductively coupled plasma mass spectrometry using an Agilent 7500 spectrometer (Agilent Techn.).

Results. This article presents the results of complex studies of groundwater and water-bearing rocks of the low-mineralized thermal waters of the Khoja-Obi-Garm, which is confined to the Pamir-Alai mountain system (Tajikistan). According to the formation conditions, the thermal waters studied belong to the fissured lead waters that circulate within the massive intrusions localized within the Alpine folding zone. According to the chemical composition, the thermal waters of the Khoja-Obi-Garm deposit belong to the chloride-sulphate $(450 \mathrm{mg} / \mathrm{l})$ hydrocarbonate sodium-siliceous waters. Water is enriched with fluorine (up to $17 \mathrm{mg} / \mathrm{l}$ ), lithium (up to 1,03 mg/l), rubidium (up to $123 \mu \mathrm{g} / \mathrm{l}$ ), cesium (about 205-230 $\mathrm{g} / \mathrm{l}$ ), arsenic (up to $5.7 \mu \mathrm{g} /$ ) and radon (up to $815 \mathrm{~Bq} / \mathrm{l}$ ). The study shown as well that rare elements in rock formations of the deposit form in accordance with their content the following sequence: $R b>T h>S c>G a>U>>C d$. The thermal waters of the field are largely enriched with $R b$, which has the highest coefficient of water migration among the rare elements, then Ga follows. The remaining elements are presented in the "trace» quantities. When moving from depth to surface, thermal waters intensively interact with water-bearing rocks, dissolve and leach them. During this process, intensive leaching of many microcomponents ( $L a, R b, Z r, B a$, Li, etc.) and their concentration in waters occur.

Key words:

Thermal waters, hydrogeological conditions, water-bearing rocks, microcomponents, Tajikistan.

The research was financially supported by the grant RFBR no. 18-05-00445. 


\section{REFERENCES}

1. Arsanova G.I. The origin of thermal waters of volcanic regions. Volcanology and seismology, 2014, no. 6, pp. 44-58. In Rus.

2. Barabanov L.N., Disler V.N. Azotnyie termy SSSR [Nitrogenous terms of the USSR]. Ed. by V.V. Ivanova. Moscow, Geominode of the Central Research Institute of KiF, 1968. 120 p.

3. Zamana L.V. Fluorine in the nitrogen waters of Transbaikalia. Geology and geophysics, 2000, vol. 41, no. 11, pp. 1575-1580. In Rus.

4. Plyusnin A.M., Cherniavsky M.K., Posokhova V.F. The conditions for the formation of the Barguzin Baikal hydrothermal fluids according to the microelement and isotopic composition data. Geochemistry, 2008, no. 10, pp. 1063-1072. In Rus.

5. Demonova A.Yu., Kharitonova N.A., Korzun A.V., Sardorov A.I., Chelnokov G.A. Chemical composition of nitrogen thermal waters of the balneoclimatic resort of Khodja-Obi-Garm (Tajikistan). Vestnik of Moscow university. Series of Geology, 2017, no. 5, pp. 77-84. In Rus.

6. Demonova A., Kharitonova N., Bragin I., Chelnokov G. Thermal waters at the western part of Pamir-Alay mountain system (Tajikistan). $11^{\text {th }}$ International Hydrogeological Congress. Athens, National technic university of Athens, 2017. Vol. 2, pp. 165-173.

7. Baskov E.A., Surikov S.N. Gidrotermy Zemli [Hydrotherms of the Earth]. Leningrad, Nedra Publ., 1989. 243 p.

8. Kiryukhin A.V., Shadrina S.V., Puzankov M.Yu. Modeling of thermohydrogeochemical conditions for the formation of productive reservoirs in volcanogenic rocks. Volcanology and seismology, 2013, no. 2, pp. 90-104. In Rus.

9. Perelman A.I. Geokhimiya elementov $v$ zone gipergeneza [Geochemistry of elements in the hypergenesis zone]. Moscow, Nedra Publ., 1972. 288 p.

10. Plyusnin A.M., Gunin V.I. Prirodnye gidrogeologicheskie sistemy, formirovanie khimicheskogo sostava i reaktsia na tekhnogennoe vozdeystvie (na primere Zabaikaliya) [Natural hydrogeological systems, the formation of chemical composition and the response to man-made impacts (for example, Transbaikalia)]. Ulan-Ude, BSC Center of the SB RAS Publ., 2001. 137 p.

11. Chudaev 0.V. Sostav i usloviya obrazovaniya sovremennykh gidrotermalnykh sistem dalnego Vostoka Rossii [Composition and conditions of formation of modern hydrothermal systems of the Far East of Russia]. Vladivostok, Dalnauka Publ., 2003. 216 p.

12. Chelnokov G., Bragin I., Kharitonova N., Chelnokova B. Hydrochemistry of low-temperature thermal water of Primorye region (Russia) and environmental implications. Water Research and Hydraulic Engineering, 2015, vol. 3, pp. 98-201.

13. Grasby S.E., Hutcheon I., Krouse H.R. The influence of waterrock interaction on the chemistry of thermal springs in western Canada. Applied Geochemistry, 2007, vol. 15, pp. 439-454.

14. Kiryuhin A., Xu T., Pruss K., Apps J., Slovtsov I. Thermal-hydrodynamic-chemical (THC) modeling based on geothermal field data. Geothermics. Techonophysics, France, 2004, vol. 33, pp. 199-214.

15. Michard G. Behaviour of major elements and some trace elements (Li, Rb, Cs, Sr, Fe, Mn, W, F) in deep hot waters from granitic areas. Chemical geology, 1990, vol. 89, pp. 117-134.

16. Kats V.E. Prirodnaya radioaktivnost geologicheskoy sredy [Natural radioactivity of the geological environment]. Radioaktivnost i radioaktivnye elementy $v$ srede obitaniya cheloveka. Materialy II megdynarodnoy konferentsii [Radioactivity and radioactive elements in the human environment. Materials of the II International Conference]. Tomsk, TPU Publ. house, 2004. pp. 549-557.

17. Gallois R.W. The formation of the hot springs at Bath Spa, UK. Geological Magazine, 2007, vol. 144, pp. 741-747.

18. Razykov B.Kh. Osobennosti razmeshcheniya i ekonomicheskaya otsenka mineralnykh vod Tadjikistana [Features of accommodation and economic evaluation of mineral waters in Tajikistan]. Dushanbe, Donish Publ., 2007. 99 p.
19. Baratov R.B. Geologiya i petrografiya rayona termalnykh istochnikov Khodga-Obi-Garm [Geology and petrography of the thermal springs of Khodzha-Obi-Garm]. Report of the Khoja-Obi-Garm Geological Party on the works of 1946. Dushanbe, 1946. $64 \mathrm{p}$.

20. Demonova A.Yu., Kharitonov N.A. Metody opredeleniya i usloviya formirovaniya khimicheskogo sostava termalnykh vod mestorozhdeniya Hodja-Obi-Garm [Methods of determination and conditions for formation of chemical composition of thermal waters of the Khodja-Obi-Garm deposit]. Morskie issledovaniya i obrazovanie (MARESEDU-2017). Trudy VI Mezhdynarodnoy naychnoprakticheskoy konferentsii [Marine Research and Education (MARESEDU-2017). Proceedings of the VI International Scientific Practical Conference]. Tver, Polipress LLC, 2017. pp. 659-663.

21. Demonova A.Yu., Bragin I.V., Razykov B.Kh. Usloviya formirovaniya termomineralnykh vod uygnykh otrogov Gissarskogo khrebta [Conditions for formation of thermomineral waters of the southern spurs of the Gissar Range]. XXI Soveshchanie po podzemnym vodam Sibibri i Dalnego Vostoka [XXI Conference on the Groundwaters of Siberia and the Far East]. Novosibirsk, Novosibirsk State University Publ., 2018. pp. 166-172.

22. Demonova A.Yu., Kharitonova N.A., Sardorov A.I. Khimicheskiy sostav termalnykh vod kyrorta Khodja-Obi-Garm [Chemical composition of thermal waters of the resort Khodja-Obi-Garm (Tajikistan)]. Sanatorno-kyrortnoe lecheniye. Materialy III Mezhdunarodnogo kongressa [Sanatorium-resort treatment. Materials of the III International Congress]. Moscow, 2017. p. 30.

23. Shapar A.A., Tuev V.G. Rezultaty razvedochnykh gidrogeologicheskikh rabot na mestorozhdenii termalnykh vod Hodja-ObiGarm [The results of exploration hydrogeological work on the thermal deposit of Khoja-Obi-Garm]. Vol. I, Comprehensive geological expedition. Dushanbe, Tajik GIINTIZ Publ., 1967. 96 p.

24. Demonova A., Kharitonova N., Sardorov A. Chemical composition of thermal waters of Khoja-Obi-Garm Spa. 42 World congress of the international society of medical hydrology and climatology. Moscow, Administration Building of the Moscow Government, 2017. p. 39.

25. Gidrogeologia SSSR [Hydrogeology of the USSR]. Vol. XLI. The Tajik SSR. Moscow, Nedra Publ., 1972. 472 p.

26. Vinogradov A.P. Srednee soderzhanie khimicheskikh elementov v glavnykh tipakh izvergennykh gornykh porod zemnoy kory [The average content of chemical elements in the main types of igneous rocks of the earth's crust]. Geochemistry, 1962, no. 7, pp. $555-571$.

27. Chudaev 0.V., Chelnokov G.A., Bragin I.V., Kharitonova N.A., Rychagov S.N., Nuzhdaev A.A., Nuzhdaev I.A. Geochemical features of the distribution of basic and rare-earth elements in the Paratunskaya and Bolshebannoye hydrothermal systems of Kamchatka. Pacific Geology, 2016, vol. 35, no. 6, pp. 102-119. InRus.

28. Shvartsev S.L. Gidrogeokhimia zony gipergeneza [Hydrogeochemistry of the hypergenesis zone]. Moscow, Nedra Publ., 1998. $287 \mathrm{p}$.

29. Shvartsev S.L. Geochemistry of Fresh Groundwater in the Main Landscape Zones of the Earth. Geochemistry International, 2008, vol. 46 , no. 13 , pp. 1-114.

30. Piscopo V., Barbieri M., Monetti V., Pagano G., Pistoni S., Ruggi E., Stanzione D. Hydrogeology of thermal waters in Viterbo area, central Italy. Hydrogeology Journal, 2006, vol. 14, pp. 1508-1521.

31. Shvartsev S.L. Fundamental mechanisms of interaction in the water-rock system and its internal geological evolution. Lithosphere, 2008, no. 6, pp. 3-24. In Rus.

32. Smyslov A.A. Uran i toriy v zemnoy kore [Uranium and thorium in the earth's crust]. Leningrad, Nedra Publ., 1974. 231 p.

Received: 18 October 2018. 


\section{Information about the authors}

Anna Y. Demonova, leading engineer, Lomonosov Moscow State University.

Natalia A. Kharitonova, Dr. Sc., professor, Lomonosov Moscow State University; chief researcher, Far Eastern Geological Institute of the Far-Eastern Branch of the Russian Academy of Sciences.

Ivan V. Bragin, Cand. Sc., senior researcher, Far Eastern Geological Institute of the Far-Eastern Branch of the Russian Academy of Sciences.

Georgiy A. Chelnokov, Cand. Sc., leading researcher, head of department and laboratory, Far Eastern Geological Institute of the Far-Eastern Branch of the Russian Academy of Sciences.

Irina A. Tarasenko, Dr. Sc., deputy director for research, Far Eastern Geological Institute of the Far-Eastern Branch of the Russian Academy of Sciences. 